\title{
Librarian Status in the Eighty-Nine U.S. Academic Institutions of the Association of Research Libraries: 1982
}

\section{Thomas G. English}

A study was conducted of the eighty-nine U.S. academic member-institutions of the Association of Research Libraries regarding the personnel status of their professional librarians. The survey elicited 100 percent participation. The results revealed that while 61.4 percent of the state institutions contacted had granted the majority of their librarians faculty status, only 18.7 percent of the private institutions had elected to do so. Also, as might be expected, the findings indicated that librarians with faculty status were more likely to receive the traditional faculty benefits and privileges of rank, tenure, research leave, sabbatical leave, and research funds, than were comparable librarians with professional (nonfaculty) status. It was also found that, among major research libraries at least, the once-popular thrust to shift academic librarians from nonfaculty to faculty status-a movement of considerable impetus in the 1960s and early 1970s-had apparently run its course. Rather, the recent personnel changes within the membership of the Association of Research Libraries were all in the opposite direction, from faculty status to a nonfaculty or modified faculty status.

nitially, a two-part questionnaire was sent to the office of academic affairs, or the equivalent administrative office, in each of the eighty-nine institutions targeted in the survey. Fifty-seven were state institutions, and thirty-two were private (table 1). Part I of the questionnaire sought current factual data on librarian status in each of the institutions contacted. Part II of the questionnaire sought the attitudes and opinions of central administrators (nonlibrarians) regarding the desirability of faculty status for academic librarians.* Opinion data was accepted only from representatives of central administration. Factual data was accepted from either central administration of the office of the university librarian. As it turned out, however, the office of the university librarian was found to have been the principal source of the factual information provided.

Collection of the data, and in particular,

"A second report, entitled "Administrator Views of Librarian Status," is in preparation by the author.

Thomas G. English is assistant professor and head, Bell Museum of Natural History Library, University of Minnesota, Minneapolis. 
its subsequent verification, proved to be a long, painstaking process, extending from April 1980 into the Winter of 1982 . During this period the author sent numerous follow-up letters and made extensive use of the telephone to clear up apparent discrepancies or omissions in the data returned. The same tactics were successfully employed to stimulate responses and to solicit explanations of unusual situations reported. At one point, the charted information in appendix A was returned to each respondent for verification of accuracy and completeness. Nearly 30 percent of the respondents took this opportunity to make minor changes in the data originally reported. Ultimately, the factual information sought was retrieved from all eighty-nine of the institutions contacted, 100 percent of the target group.

\section{Terminology}

The author used the word "professional" to denote the several categories of librarian status not designated as faculty. Thus, returns which indicated academic or administrative status for librarians were interpreted as "professional." (Definitions of other terms used in this report are included in appendix A.)

\section{Factual \\ Information Sought}

Respondents were asked to report the personnel status of librarians, types of final appointments accorded, ranks assigned, benefits and privileges, criteria used to evaluate performances, and plans if any, to effect significant changes in librarian personnel status. *

\section{PERSONNEL STATUS}

Based on responses from all eighty-nine institutions, it was found that major private institutions were much less likely to grant faculty status to librarians than were comparable state institutions (tables 2 and $3)$. Whereas thirty-five of the fifty-seven state institutions (61.4 percent) reported that they had granted faculty status to their librarians, only six of the thirty-two private institutions (18.7 percent) reported that they had done so. In some instances, established groups of institutions appeared to be in complete or nearly complete agreement regarding the assignment of librarian status. For example, it was found that, with the exception of Missouri, all of the Big-Eight institutionsColorado, Iowa State, Kansas, Kansas State, + Nebraska, Oklahoma, and Oklahoma State, had accorded faculty status to their librarians. Conversely, all the Ivy League institutions-Brown, Columbia, Cornell, Dartmouth, Harvard, Pennsylvania, Princeton, and Yale, had elected to place their librarians in a professional classification. On the other hand, returns from a third group of institutions, the BigTen, indicated that its members were in extensive disagreement over the status issue. Of the Big-Ten, six institutions, Indiana, Iowa, Michigan, Michigan State, Northwestern, and Wisconsin, reported professional status for the majority of their librarians, while the remaining four, Illinois, Minnesota, Ohio State, and Purdue, indicated that the majority of their librarians had faculty status. Furthermore, Minnesota, Purdue, and Wisconsin reported a mixture of professional and faculty positions. Faculty positions were in the majority at Minnesota by a ratio of three-to-one, and at Purdue by a ratio of more than sixto-one. Professional positions were in the majority at $\mathrm{Wisconsin}$, by a ratio of slightly more than two-to-one.

As of May 1982, the library staff at the University of Wisconsin-Madison was reported to consist of twenty-six faculty positions, and slightly more than twice that number of academic (nonfaculty) posi-

\footnotetext{
*Several institutions reported two distinct personnel classifications for their librarians. In such instances, the majority situation was indicated in the tables, and explanations were provided in the text of the report.

tKansas State, the only Big-Eight institution that was not a member of ARL, was queried in regard to librarian status. However, no other data from Kansas State was included in the survey results.
} 
TABLE 1

LIST OF INSTITUTIONS SURVEYED

\begin{tabular}{|c|c|c|}
\hline \multicolumn{2}{|c|}{ State Institutions (57) } & $\begin{array}{c}\text { Private } \\
\text { Institutions (32) }\end{array}$ \\
\hline Alabama & Nebraska & Boston \\
\hline Arizona & New Mexico & Brigham Young \\
\hline Arizona State & North Carolina & Brown \\
\hline California, Berkeley & Ohio State & Case Western \\
\hline California, Davis & Oklahoma & Chicago \\
\hline California, Los Angeles & Oklahoma State & Columbia \\
\hline California, Riverside & Oregon & Cornell \\
\hline California, San Diego & Penn State & Dartmouth \\
\hline California, Santa Barbara & Purdue & Duke \\
\hline Cincinnati & Rutgers & Emory \\
\hline Colorado & South Carolina & Georgetown \\
\hline Colorado State & Southern Illinois & Harvard \\
\hline Connecticut & SUNY-Albany & Howard \\
\hline Florida & SUNY-Buffalo & Johns Hopkins \\
\hline Florida State & SUNY-Stony Brook & MIT \\
\hline Georgia & Texas & Miami \\
\hline Hawaii & Texas A\&M & New York \\
\hline Houston & Tennessee & Northwestern \\
\hline Indiana & Utah & Notre Dame \\
\hline Illinois & Virginia & Pennsylvania \\
\hline Iowa & Virginia Poly & Pittsburgh \\
\hline Iowa State & Washington (Seattle) & Princeton \\
\hline Kansas & Washington State & Rice \\
\hline Kent State & Wayne & Rochester \\
\hline Kentucky & Wisconsin & Southern California \\
\hline Louisiana State & & Stanford \\
\hline Maryland & & Syracuse \\
\hline Massachusetts & & Temple \\
\hline Michigan & & Tulane \\
\hline Michigan State & & Vanderbilt \\
\hline Minnesota & & Washington (St. Louis) \\
\hline Missouri & & Yale \\
\hline
\end{tabular}

tions. Most of the faculty appointments were upper and middle management positions, such as directors, assistant directors, division heads, and department heads, but also included some bibliographers. ${ }^{1} \mathrm{~A}$ few faculty librarians, because of their special academic qualifications, held joint tenured appointments in an outside department or discipline. However, the most recent faculty appointments were reported to have been made only at upper management levels. ${ }^{2}$ Librarians with faculty status were accorded traditional faculty ranks, and were eligible for tenure. Nonfaculty librarians were called "specialists," but a different series, using the titles "assistant librarian," "'associate librarian," and "librarian," was under consideration. Nonfaculty appointees were eligible for "indefinite appointments," and were reviewed for that status by an appropriate external standing committee, as well as internal library staff. Each individual tenure case being considered was reviewed by ad hoc committees appointed by the chancellor. Reportedly, the performance criteria used were the same for either kind of appointment: (1) effectiveness of job performance, and (2) scholarly ability, continuing professional growth, and effectiveness of service to the institution.

Two other institutions reported that sig-

TABLE 2

PERSONNEL STATUS OF THE MAJORITY OF LIBRARIANS (BY NUMBER OF INSTITUTIONS)

\begin{tabular}{lcr}
\hline & State (57) & \multicolumn{1}{c}{ Private (32) } \\
\hline Faculty status & $35(61.4 \%)$ & $6(18.7 \%)$ \\
$\begin{array}{l}\text { Professional } \\
\quad \text { status }\end{array}$ & $22(38.6 \%)$ & $26(81.3 \%)$ \\
$\quad$ Totals & $57(100 \%)$ & $32(100 \%)$ \\
\hline
\end{tabular}


TABLE 3

LIST OF INSTITUTIONS BY PERSONNEL STATUS OF LIBRARIANS

\begin{tabular}{|c|c|c|c|}
\hline $\begin{array}{l}\text { Reporting Faculty } \\
\text { Status for } \\
\text { Librarians (35) }\end{array}$ & $\begin{array}{l}\text { utions (57) } \\
\text { Reporting Nonfaculty } \\
\text { Status for } \\
\text { Librarians (22) }\end{array}$ & $\begin{array}{l}\text { Private } \\
\text { Reporting Faculty } \\
\text { Status for } \\
\text { Librarians (6) }\end{array}$ & $\begin{array}{l}\text { itutions (32) } \\
\text { Reporting Nonfaculty } \\
\text { Status for } \\
\text { Librarians (26) }\end{array}$ \\
\hline $\begin{array}{l}\text { Alabama } \\
\text { Arizona } \\
\text { Arizona State } \\
\text { Colorado } \\
\text { Colorado State } \\
\text { Florida } \\
\text { Hawaii } \\
\text { Houston } \\
\text { Illinois } \\
\text { Iowa State } \\
\text { Kansas } \\
\text { Kent State } \\
\text { Kentucky } \\
\text { LSU } \\
\text { Minnesota } \\
\text { Nebraska } \\
\text { New Mexico } \\
\text { Ohio State } \\
\text { Oklahoma } \\
\text { Oklahoma State } \\
\text { Oregon } \\
\text { Penn State } \\
\text { Purdue } \\
\text { Rutgers } \\
\text { South Carolina } \\
\text { Southern Illinois } \\
\text { SUNY-Albany } \\
\text { SUNY-Buffalo } \\
\text { SUNY-Stony Brook } \\
\text { Texas A\&M } \\
\text { Tennessee } \\
\text { Virginia } \\
\text { Virginia Poly } \\
\text { Washington State } \\
\text { Wayne State } \\
\text { Wuato }\end{array}$ & $\begin{array}{l}\text { California, Berkeley } \\
\text { California, Davis } \\
\text { California, Los Angeles } \\
\text { California, Riverside } \\
\text { California, San Diego } \\
\text { California, Santa Barbara } \\
\text { Cincinnati } \\
\text { Connecticut } \\
\text { Florida State } \\
\text { Georgia } \\
\text { Indiana } \\
\text { Iowa } \\
\text { Maryland } \\
\text { Massachusetts } \\
\text { Michigan } \\
\text { Michigan State } \\
\text { Missouri } \\
\text { North Carolina } \\
\text { Texas } \\
\text { Utah } \\
\text { Washington (Seattle) } \\
\text { Wisconsin }\end{array}$ & $\begin{array}{l}\text { Brigham Young } \\
\text { Miami } \\
\text { New York } \\
\text { Notre Dame } \\
\text { Pittsburgh } \\
\text { Southern California }\end{array}$ & $\begin{array}{l}\text { Boston } \\
\text { Brown } \\
\text { Case Western Reserve } \\
\text { Chicago } \\
\text { Columbia } \\
\text { Cornell } \\
\text { Dartmouth } \\
\text { Duke } \\
\text { Emory } \\
\text { Georgetown } \\
\text { Harvard } \\
\text { Howard } \\
\text { Johns Hopkins } \\
\text { MIT } \\
\text { Northwestern } \\
\text { Pennsylvania } \\
\text { Princeton } \\
\text { Rice } \\
\text { Rochester } \\
\text { Stanford } \\
\text { Syracuse } \\
\text { Temple } \\
\text { Tulane } \\
\text { Vanderbilt } \\
\text { Washington (St. Louis) } \\
\text { Yale }\end{array}$ \\
\hline
\end{tabular}

nificant numbers of their librarians were placed in two distinct personnel categories. The University of Houston* reported that its library staff was divided into twenty-one faculty, and twenty professional appointees. The University of Oregon reported that 35 percent of its librarians were classed as officers of instruction-the same personnel category as the regular teaching faculty-while the great majority ( 65 percent) were classed as officers of administration, a second faculty category at the University of Oregon.* And finally, Harvard, which reported that its librarians were placed in a professional category, indicated the presence of eight faculty librarian positions from a total staff of 228 .

\section{TYPES OF APPOINTMENTS}

The types of final appointments accorded librarians in the institutions contacted are summarized in table 4 . Thirtyeight of eighty-nine institutions (42.7 percent) reported that librarians were accorded indefinite tenure. Forty-one institutions (46.1 percent) indicated that

*The dual personnel systems at Oregon, Houston, Minnesota, and Purdue are discussed in greater detail in a later section of the report. 
TABLE 4

TYPES OF FINAL APPOINTMENTS THAT

MAY BE ACHIEVED BY THE MAJORITY

OF THE LIBRARY STAFF (BY NUMBER OF INSTITUTIONS)

\begin{tabular}{lcr}
\hline \hline & State (57) & \multicolumn{1}{c}{ Private (32) } \\
\hline $\begin{array}{l}\text { Indefinite tenure } \\
\text { Continuing }\end{array}$ & $34(59.7 \%)$ & $4(12.5 \%)$ \\
$\begin{array}{l}\text { appointments } \\
\text { Term appointments }\end{array}$ & $19(33.3 \%)$ & $22(68.8 \%)$ \\
$\quad$ Totals & $57(100 \%)$ & $6(18.0 \%)$ \\
\hline
\end{tabular}

librarians were granted continuing appointments. And, ten of the eighty-nine institutions (11.2 percent) reported that librarians were given term appointments. In general, continuing appointments were perceived by respondents as nearly identical to those of tenure, in that the term of appointment was considered to be indefinite. By the same token, term appointments were sometimes described by respondents as de facto continuing appointments, in that the renewal of such appointments was virtually automatic.

\section{TYPES OF RANK}

The ranks assigned librarians from the institutions queried are summarized in table 5 . Twenty-one of the eighty-nine institutions (23.6 percent) reported that their librarians were assigned faculty ranks. Twenty-eight institutions ( 31.4 percent) reported the use of equivalent ranks. * Thirty-three institutions (37.1 percent) reported numerical ranks, and seven of the eighty-nine institutions (07.9 percent) reported that librarians were given ranks or titles other than those listed. Usually, individuals were given both a rank and title, such as "art librarian," or "slavic bibliographer."

\section{BENEFITS AND PRIVILEGES}

The benefits and privileges accorded librarians in the institutions surveyed are summarized in tables 6 and 7. All eightynine of the institutions contacted reported the provision of pensions for their librari- ans, and all indicated the provision of travel funds, under prescribed conditions, subject to the general availability of funds. But, with the exception of tuition assistance, librarians in state institutions were, on an average, more likely to receive the benefits and privileges listed (table 6 ). However, the key to the differences in benefits and privileges between state and private institutions was found to be the much higher incidence of faculty status within state institutions. Based on the data presented in table 7 , librarians with faculty status were much more likely to be accorded the traditional faculty benefits and privileges of rank, tenure, sabbatical leave, and research funds.

\section{PERFORMANCE CRITERIA}

The criteria used in the evaluation of librarian performance fell into three general categories (table 8). Fifty-two of the eighty-nine institutions (58.4 percent) reported the use of professional criteria in the evaluation of librarian performance. Twenty-two institutions ( 24.7 percent) reported the use of an amended version of faculty criteria, while only fifteen of the eighty-nine institutions (16.9 percent) indicated the use of traditional faculty criteria in the evaluation of librarian performance-a rather striking fact, considering that forty-one of the institutions surveyed reported faculty status for their librarians. Furthermore, an analysis of fourteen of the fifteen institutions that checked "same as teaching faculty," revealed that most used a blend of profes-

\section{TABLE 5}

TYPES OF RANK ASSIGNED THE MAJORITY OF LIBRARIANS (BY NUMBER OF INSTITUTIONS)

\begin{tabular}{lcr}
\hline & State (57) & Private (32) \\
\hline Faculty rank & $20(35.1 \%)$ & $1(03.1 \%)$ \\
$\begin{array}{l}\text { Equivalent } \\
\text { rank }\end{array}$ & $21(36.8 \%)$ & $7(21.9 \%)$ \\
$\begin{array}{l}\text { Numerical } \\
\text { rank }\end{array}$ & $13(22.8 \%)$ & $20(62.5 \%)$ \\
$\begin{array}{l}\text { Other } \\
\quad \text { Totals }\end{array}$ & $3(05.3 \%)$ & $4(12.5 \%)$ \\
\hline
\end{tabular}

^Equivalent rank denotes assistant librarian, associate librarian, and librarian. 
TABLE 6

BENEFITS AND PRIVILEGES OF LIBRARIANS IN STATE

INSTITUTIONS VERSUS LIBRARIANS IN PRIVATE

INSTITUTIONS (BY NUMBER OF INSTITUTIONS)

\begin{tabular}{lcr}
\hline & State $(57)$ & Private (32) \\
\hline Faculty rank & $20(35.1 \%)$ & $1(03.1 \%)$ \\
Indefinite tenure & $34(59.6 \%)$ & $4(12.5 \%)$ \\
Pension & $57(100 \%)$ & $32(100 \%)$ \\
Research funds & $51(89.5 \%)$ & $13(40.6 \%)$ \\
Travel funds & $57(100 \%)$ & $32(100 \%)$ \\
Research leave & $47(82.5 \%)$ & $25(78.1 \%)$ \\
Sabbatical leave & $35(61.4 \%)$ & $10(31.3 \%)$ \\
Tuition break & $41(71.9 \%)$ & $28(87.5 \%)$ \\
Option of nine-month appointment & $15(26.3 \%)$ & $7(21.9 \%)$ \\
\hline
\end{tabular}

TABLE 7

BENEFITS AND PRIVILEGES OF LIBRARIANS VERSUS NONFACULTY LIBRARIANS (BY NUMBER OF INSTITUTIONS)

\begin{tabular}{lcc}
\hline & $\begin{array}{c}\text { Librarians with } \\
\text { Faculty Status } \\
\text { Forty-one (41) } \\
\text { Institutions }\end{array}$ & $\begin{array}{c}\text { Librarians with } \\
\text { Nonfaculty Status } \\
\text { Forty-eight (48) } \\
\text { Institutions }\end{array}$ \\
\hline Faculty rank & $21(51.2 \%)$ & $0(00.0 \%)$ \\
Indefinite tenure & $37(90.2 \%)$ & $1(02.1 \%)^{\star}$ \\
Pension & $41(100 \%)$ & $48(100 \%)$ \\
Research funds & $36(87.8 \%)$ & $28(58.3 \%)$ \\
Travel funds & $41(100 \%)$ & $48(100 \%)$ \\
Research leave & $34(82.9 \%)$ & $38(79.2 \%)$ \\
Sabbatical leave & $34(82.9 \%)$ & $10(20.8 \%)$ \\
Tuition break & $29(70.7 \%)$ & $42(87.5 \%)$ \\
Option of nine-month appointment & $12(29.3 \%)$ & $12(25.0 \%)$ \\
\hline
\end{tabular}

*Indiana reported that its librarians were placed in a special academic category (nonfaculty), parallel to the faculty, and with the provision of indefinite tenure.

TABLE 8

CRITERIA USED FOR THE EVALUATION OF LIBRARIAN PERFORMANCE (BY NUMBER OF INSTITUTIONS)

\begin{tabular}{lcr}
\hline & State $(57)$ & Private (32) \\
\hline Same as teaching faculty & $14(24.6 \%)$ & $1(03.1 \%)$ \\
Modified version of teaching faculty criteria & $17(29.8 \%)$ & $5(15.6 \%)$ \\
A set of professional criteria & $26(45.6 \%)$ & $26(81.3 \%)$ \\
Totals & $57(100 \%)$ & $32(100 \%)$ \\
\hline
\end{tabular}

sional and faculty criteria.* A review of the listed criteria (appendix B) revealed that in virtually every instance, professional criteria such as librarianship, job performance, collection development, professional effectiveness, and reference services, were linked together with the traditional faculty criteria of teaching, scholarship, and research. The survey results did not disclose a single case in which strictly faculty criteria were listed for the evaluation of librarian perform- ance. Rather, it appeared that librarians with faculty status were characteristically required to meet two distinct sets of criteria: one set designed to measure performance as librarians, and the other set designed to measure performance as faculty.

\section{CHANGES IN PERSONNEL STATUS}

The data summarized in table 9 revealed that U.S. academic members of the Association of Research Libraries were no longer inclined to shift librarians from

*The fifteenth institution did not provide a written list of criteria. 
TABLE 9

INSTITUTIONS REPORTING THE POSSIBILITY OF MOVING

SOME, OR ALL, LIBRARIANS INTO A DIFFERENT PERSONNEL CLASSIFICATION (BY NUMBER OF INSTITUTIONS)

\begin{tabular}{lcr}
\hline & State $(57)$ & Private (32) \\
\hline From faculty to nonfaculty & $4(07.0 \%)$ & $0(00.0 \%)$ \\
From nonfaculty to faculty & $0(00.0 \%)$ & $0(00.0 \%)$ \\
Neither change was contemplated & $53(93.0 \%)$ & $32(100 \%)$ \\
\multicolumn{1}{c}{ Totals } & $57(100 \%)$ & $32(100 \%)$ \\
\hline
\end{tabular}

nonfaculty to faculty status, as was commonly done in the 1960 s and early 1970 s. Instead, the few changes that were indicated in the survey were in the opposite direction, from faculty status to a nonfaculty, or modified faculty classification.

Two cases involving the shift of librarians from faculty to professional status were known to have occurred several years prior to the present study. A brief insert in the June 1977 issue of the Mountain Plains Library Association Newsletter stated in part: "On May 2, 1977, the Academic Senate of the University of Utah voted to approve an academic committee's recommendation changing the status of the university librarians from faculty rank to a newly-created 'librarian' rank. ${ }^{\prime \prime 3}$ Based on the data returned in the survey, all the tenured librarians retained faculty status. * All the remaining librarian positions at the University of Utah were switched, en masse, from tenure-track status to an academic, nonfaculty status. And, all future librarian appointees at Utah were to be placed in the academic series.

The second such case was that of the University of Houston. At Houston, policy changes governing librarian classification evolved gradually over a period of several years. In 1978, after "a superb reference librarian" had been terminated for failing to meet the traditional faculty criteria for tenure, the university librarian, with the support of the library staff, approached central administration with the proposal that, henceforth, library faculty appointees be evaluated by a set of performance criteria specifically fitted to librarian activities and responsibilities. ${ }^{4}$ The administration countered with the proposal that all untenured librarians con- sider the option of switching their appointments to an existing nonfaculty personnel classification. Nearly one-half the library staff chose to switch their appointments to the nonfaculty category, to be evaluated by a set of professional criteria. A slight majority, including all the tenured librarians, elected to retain faculty status, with the understanding that the criteria used for their evaluation would emphasize the traditional faculty tenure requirements. However, information provided the author in late 1982 revealed that continuing problems with the criteria, coupled with the awkwardness of the dual personnel scheme, led to the decision to completely eliminate the option of faculty appointments for librarians at Houston. Tenured librarians were not affected. But all untenured librarians at Houston were placed in the "academic" category, "with most of the benefits of faculty status, but none of the drawbacks. ${ }^{\prime 5}$

Returning to the data collected in the present survey, respondents of four institutions, Colorado, Minnesota, Oregon, and Purdue, indicated varying degrees of institutional dissatisfaction with faculty status for librarians. The issue arose at the University of Colorado when a campuswide faculty review committee found the content of librarian dossiers to be substantially different from dossiers submitted by the regular teaching faculty. ${ }^{6}$ Consequently, the committee requested that it not be asked to consider such dossiers, and that they be forwarded directly to the office of academic affairs for further review and discussion. After months of debate it was concluded that faculty status might be inappropriate for librarians, because the traditional faculty performance

${ }^{\star}$ Five positions in the general library system, and two positions in the bio-medical and law libraries. 
criteria appeared to be largely unsuited to librarian activities and responsibilities. However, officials of the institution were apparently unable to agree on a possible remedy for the situation. For a time it was thought that all new librarian appointees would be placed in a nonfaculty personnel category. But, as recently as November $1982,{ }^{7}$ the issue had not changed, being described by the administrator respondent to the survey as "dormant." Meanwhile, librarians due for promotion or tenure at the University of Colorado were treated somewhat differently from the regular teaching faculty, in that the campus-wide review committee was not involved in the process.

According to the administrator respondent from the University of Oregon, a significant number of librarians were placed in increasing jeopardy because of the difficulty of meeting faculty tenure requirements. ${ }^{8}$ Consequently, in 1980 , as a result of a long history of debate, librarians at the University of Oregon were presented with the choice of remaining officers of instruction, the same personnel category as the teaching faculty, or becoming officers of administration, a second faculty category, according to officials at the University of Oregon. "The purpose of the shift was to remove from professional librarians some of the burden of research and publication required of those teaching faculty members who achieve promotion and tenure. ${ }^{\prime \prime}$ Librarians who chose to convert their appointments to the administrative category were to retain traditional faculty ranks and all other faculty prerequisites. However, tenure was not available to officers of administration. Instead, these appointees were eligible for three-year term appointments. In November 1980, according to the university librarian, ${ }^{10}$ roughly 50 percent of the library staff at Oregon elected to switch to the officer of administration category. At the same time, it was concluded that all new librarian appointees would be placed in the latter classification. Consequently, by April 1982, through attrition, the ratio had shifted from 65 percent officers of administration to 35 percent officers of instruction. And, it was projected that, by 1990 , the conversion to officers of administration would be complete.

At the University of Minnesota, persistent problems with the interpretation of faculty performance criteria for librarians led to the conclusion that at least some librarian positions were inappropriately classed as faculty. Thus, in December 1980 , when a new academic staff classification was adopted by the institution, a new professional librarian series was included. Performance criteria for the librarian series focused largely on specific dayto-day work activities and responsibilities. Prospective appointees were offered equivalent ranks, rather than faculty ranks, and continuing appointments, rather than tenure. As of May 1, 1982, fifteen positions had been established in the new series, all situated in systems, technical services, or interlibrary loan activities. Five of the fifteen positions were occupied by individuals who had elected to switch from faculty, tenure-track appointments to the new professional classification. And, although faculty positions remained in the majority at Minnesota by a ratio of more than three-to-one, it was anticipated that, in the future, additional conversions of faculty positions would occur, as tenured librarians vacated their positions. In August 1982 it was officially concluded that all new librarian appointees at Minnesota would be placed in the professional series. ${ }^{11}$

At Purdue University, similar problems with promotion and tenure requirements brought about a policy change within the libraries, which was designed to separate technical service positions from those in public services. On July 1, 1981, with the consent of the individuals affected, all the untenured catalogers and systems librarians at Purdue (six positions) were transferred from tenure-track appointments to a professional classification. * But, faculty

\footnotetext{
*No case was found in any of the eighty-nine institutions surveyed in which a tenured librarian had relinquished faculty status or tenure.
} 
librarian positions remained in the majority at Purdue by a ratio of more than six-toone.

\section{SUMMARY OF FINDINGS}

A survey was conducted of the eightynine U.S. academic institutions of the Association of Research Libraries regarding the personnel status of their professional librarians. The principal findings were:

1. State institutions were more than three times more likely to grant librarians faculty status than were private institutions.

2. Of the three types of final appointments reported for librarians, continuing appointments ( 46.1 percent) were slightly more prevalent than indefinite tenure (42.7 percent). Only ten institutions (11.2 percent) reported that their librarians were given term appointments.

3 . Thirty-seven of the forty-one institutions who reported faculty status for their librarians also reported the provision of indefinite tenure for their librarians. Only one of the forty-eight institutions that reported professional (nonfaculty) status for its librarians also reported the provision of tenure for its librarians.

4. There was wide variation, among the institutions surveyed, in the assignment of rank to librarians. Numerical ranks (37.1 percent) were the most popular choice, with equivalent ranks (31.4 percent) second, and traditional, faculty ranks (23.6 percent) third in frequency. Usually individuals were given both rank and a descriptive title, such as "art librarian," or "slavic bibliographer."

5. Only twenty-one of the forty-one institutions that reported faculty status for their librarians also reported that the majority of their librarians were assigned traditional faculty ranks.

6. Librarians with faculty status were much more likely to receive traditional faculty benefits and privileges such as rank, tenure, research funds, and sabbatical leave, than were librarians with professional status.

7. Three different categories of librarian performance criteria were reported by the institutions surveyed. Over half ( 58.4 percent) reported the use of professional criteria in the evaluation of librarian performance, while a fourth ( 24.7 percent) reported the use of an amended version of faculty criteria. Only fifteen institutions (16.9 percent) claimed that the criteria used for evaluating librarian performance were the same as those used for the regular teaching faculty. But an analysis of the criteria listed by the latter group of institutions revealed that virtually all used a combination of both professional and faculty criteria. The study did not disclose a single instance in which faculty criteria alone were used in the evaluation of librarian performance.

8. Librarians with faculty status were characteristically required to meet two distinct sets of criteria: one set designed to measure performance as librarians; the other set designed to measure performance as faculty. And, in a few institutions, librarians with professional (nonfaculty) status were required to meet very similar dual sets of criteria. In either case, the weight given one set of criteria, in proportion to the other, could not be determined from the data received.

9. Among the institutions surveyed, members were no longer inclined to shift librarians from nonfaculty to faculty status, as was commonly done in the sixties and early seventies. Rather, the few, recent changes reported were all in the opposite direction, from faculty status to a nonfaculty or modified faculty status. Difficulties encountered in the interpretation of faculty performance criteria for librarians were found to be at the heart of these changes.

10. Not one case was found in any of the eighty-nine institutions surveyed in which a tenured librarian had relinquished faculty status or tenure.

\section{REFERENCES}

1. Joseph Treyz, letter to author, 18 May 1982. 
2. Bryant Kearl, letter to author, 18 October 1982.

3. "University of Utah Librarians Lose Faculty Status; Retain Academic Status," Mountain Plains Library Association. Newsletter 21:7 (June 1977).

4. Thomas W. Shaughnessy, telephone interview with author, 14 December 1981.

5. letter to author, 17 November 1982.

6. Brangwyn Foote, telephone interview, 21 January 1982.

7. letter to author, 2 November 1982.

8. Robert C. Albrecht, telephone interviews with author, 7 August 1980, and 27 February 1982.

9. letter to author, 30 December 1981.

10. George W. Shipman, letters to author, 29 April 1982, and 14 May 1982.

11. Kenneth H. Keller, vice-president for Academic Affairs, University of Minnesota, letter to Eldred Smith, university librarian, University of Minnesota, 12 August 1982.

\section{APPENDIX A: BENEFITS AND PRIVILEGES OF ARL LIBRARIANS: 1982}

\section{Explanation of Column Headings Used in Appendix A}

Column 1. Type of Institution: State (s) or Private (p).

Column 2. Faculty Rank (x): Assistant Professor, Associate Professor, etc.; Equivalent Rank (e): Assistant Librarian, Associate Librarian, etc.; Numerical Rank (n): Librarian I, II, III, IV; Other (o): Usually descriptive titles, e.g., "Art Librarian."

Column 3. Indefinite Tenure: Permanence of appointment, whose purpose is the protection of academic freedom.

Column 4. Continuing Appointment: Similar to tenure, in that the term of appointment is indefinite, following the successful transition of a probationary period. For purposes of this study, such expressions as "career status" or "indefinite appointment" were interpreted to be variations of continuing appointments.

Term Appointment: A renewable contract, usually of 1-3 years duration.

Column 5. Pension: Retirement plan. Institution contributes share.

Column 6. Research Funds: Funds that are made available, often on a competitive basis, for materials, clerical assistance, research assistance, etc.

Column 7. Travel Funds: Generally, monies that are made available to compensate staff members whose professional needs and obligations necessitate travel.

Column 8. Research Leave: Leave granted for the purpose of carrying out well-structured, clearly defined research, usually with full or part salary.

Column 9. Sabbatical Leave: From the word "sabbath," to rest. Traditionally, a year's leave of absence on half pay (there are several variations). An opportunity for elected research, but also a time of reflection and renewal.

Column 10. Tuition Break: Institutional support (all or part) of the appointee's tuition expenses. Usually limited to one course per term, with administrative approval.

Column 11. Option of Nine-Month appointment (including variations up to 10.5 months).

Column 12. Status: Faculty $(\mathrm{F})$ or Professional $(\mathrm{P})$. The personnel status of the majority of the professional library staff. For purposes of this study, the terms "classified," "administrative," "staff," and "academic" were interpreted to be variations of professional (nonfaculty) status.

Note: Whenever librarians in a single institution were found to be placed in two different classifications, the author chose to designate the majority of appointees. For example $F(2)$ signifies that the majority of librarian positions were faculty, but that there were also significant numbers of nonfaculty positions within the same staff. Similarly, the entries for rank, tenure, and continuing appointments indicate the majority where other conditions also exist. 


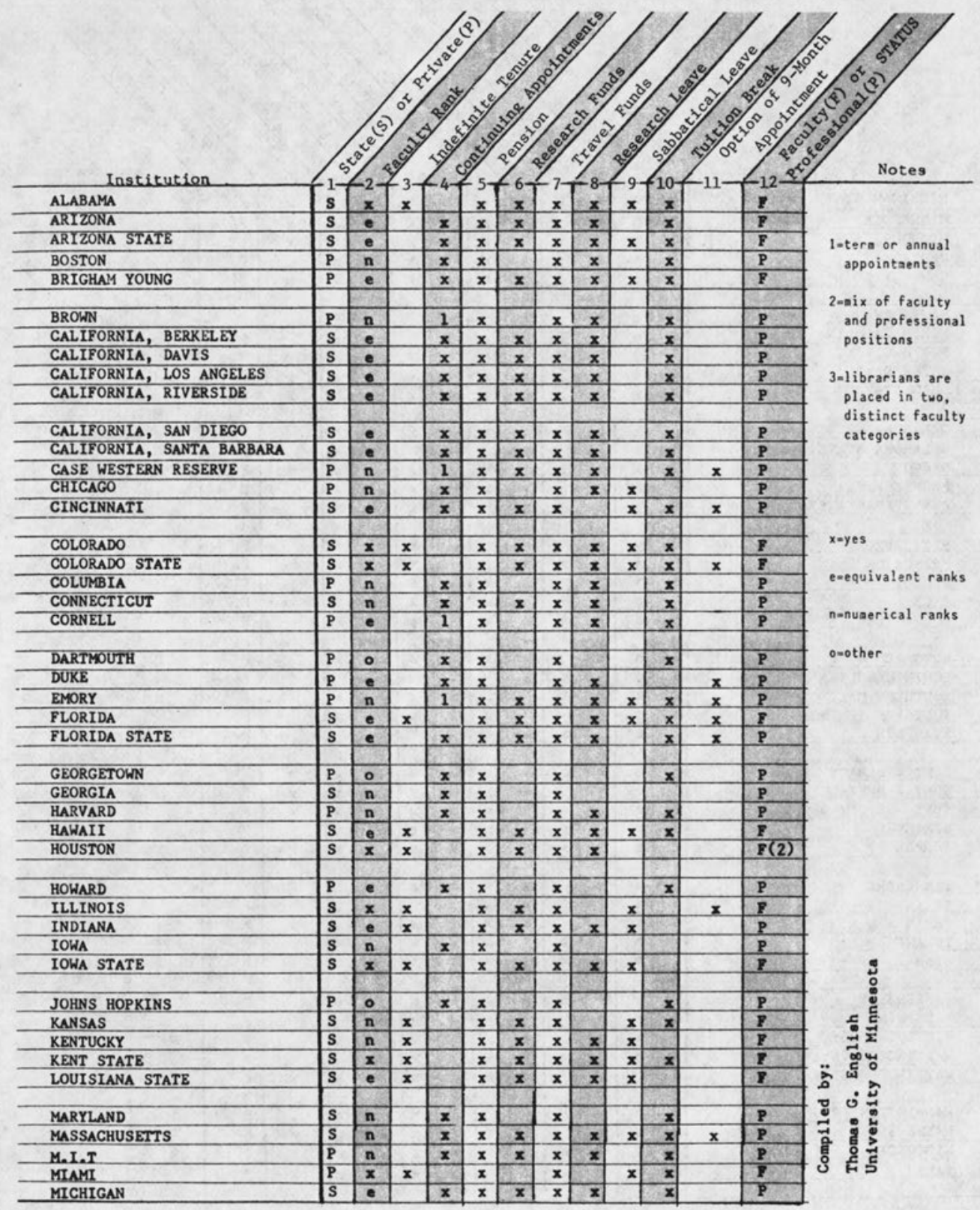









\section{APPENDIX B: THE CRITERIA LISTED BY RESPONDENTS THAT CHECKED "SAME AS TEACHING FACULTY" (TABLE 8)}

Alabama: (1) Excellence in the performance of assigned duties (Reference and research assistance, collection development, organization of collections, orientation of patrons). (2) Excellence in instruction (adjunct professorships, lectures, workshops, internship guidance).

Houston: (1) Professional effectiveness. (2) Scholarly achievement.

Illinois: (1) Librarianship. (2) Teaching.

Kent State: (1) Job performance. (2) Research/scholarship; may be demonstrated either through publication or additional education.

Minnesota: (1) Research: distinction in the development of University Libraries' research collections, in the effective extension of bibliographic control over these collections, and in other substantive research contributions. (2) Teaching: effectiveness in providing reference and information service, including one-to-one instruction, lectures, courses, the preparation of bibliographic and instructional aids, and other forms of teaching.

Nebraska: (1) Work performance. (2) External professional contributions and activities.

New Mexico: (1) Job performance. (2) Research.

Ohio State: (1) Teaching performance (Performance equated with teaching in one's assigned role as librarian). (2) Research and publication performance. (3) Professional/community service.

Oklahoma: (1) Librarianship. (2) Service.

Purdue: (1) Excellence in librarianship. (2) Research and publication.

Rutgers: (1) Professional effectiveness-equivalent to teaching effectiveness of the teaching faculty. (2) General usefulness.

Southern Illinois: (1) Instructional support-competence in one's professional assignment (comparable to teaching). (2) Research and publication; creative activity. (3) Service.

Tennessee: (1) Performance as a librarian. (2) Scholarship, research, creative accomplishment, or professional development.

New York University: (1) Service. (2) Academic achievement; publication. (3) Professional participation.

Note: The fifteenth institution, Oregon, did not list criteria.

\section{INDEX ALERT}

The Index for Volumes 26 to 40 (1965-1979) of College \& Research Libraries and College \& Research Libraries News, prepared by Eldon W. Tamblyn, has been published and is now available from ACRL. Many items in CERL News which are not indexed anywhere else in library literature appear in this 63-page cumulation. Prices are $\$ 10$ for ACRL members and $\$ 12$ for nonmembers. Order from the ACRL office, 50 East $\mathrm{Hu}$ ron Street, Chicago, IL 60611. Payment must accompany all orders. 